\title{
Sphingosine 1-phosphate turnover (version 2019.4) in the IUPHAR/BPS Guide to Pharmacology Database
}

\author{
Nigel J Pyne ${ }^{1}$ and Susan Pyne ${ }^{1}$
}

1. University of Strathclyde, UK

\begin{abstract}
S1P (sphingosine 1-phosphate) is a bioactive lipid which, after release from cells via certain transporters, acts as a ligand for a family of five S1P-specific G protein-coupled receptors (S1P1-5). However, it also has a number of intracellular targets. S1P is formed by the ATP-dependent phosphorylation of sphingosine, catalysed by two isoforms of sphingosine kinase (EC 2.7.1.91). It can be dephosphorylated back to sphingosine by sphingosine 1-phosphate phosphatase (EC 3.1.3) or cleaved into phosphoethanolamine and hexadecenal by sphingosine 1phosphate lyase (EC 4.1.2.27). Recessive mutations in the S1P lyase (SPL) gene underlie a recently identified sphingolipidosis: SPL Insufficiency Syndrome (SPLIS). In general, S1P promotes cell survival, proliferation, migration, adhesion and inhibition of apoptosis. Intracellular S1P affects epigenetic regulation, endosomal processing, mitochondrial function and cell proliferation/senescence. S1P has myriad physiological functions, including vascular development, lymphocyte trafficking and neurogenesis. However, S1P is also involved in a number of diseases such as cancer, inflammation and fibrosis. Therefore, its GPCRs and enzymes of synthesis and degradation are a major focus for drug discovery.
\end{abstract}

\section{Contents}

This is a citation summary for Sphingosine 1-phosphate turnover in the Guide to Pharmacology database (GtoPdb). It exists purely as an adjunct to the database to facilitate the recognition of citations to and from the database by citation analyzers. Readers will almost certainly want to visit the relevant sections of the database which are given here under database links.

GtoPdb is an expert-driven guide to pharmacological targets and the substances that act on them. GtoPdb is a reference work which is most usefully represented as an on-line database. As in any publication this work should be appropriately cited, and the papers it cites should also be recognized. This document provides a citation for the relevant parts of the database, and also provides a reference list for the research cited by those parts.

Please note that the database version for the citations given in GtoPdb are to the most recent preceding version in which the family or its subfamilies and targets were substantially changed. The links below are to the current version. If you need to consult the cited version, rather than the most recent version, please contact the GtoPdb curators.

\section{Database links}

Sphingosine 1-phosphate turnover 
http://www.guidetopharmacology.org/GRAC/FamilyDisplayForward?familyld=776

Sphingosine kinase

http://www.guidetopharmacology.org/GRAC/FamilyDisplayForward?familyld=787

Enzymes

SPHK1(sphingosine kinase 1)

http://www.guidetopharmacology.org/GRAC/ObjectDisplayForward?objectld=2204

SPHK2(sphingosine kinase 2)

http://www.guidetopharmacology.org/GRAC/ObjectDisplayForward?objectld=2205

Sphingosine 1-phosphate phosphatase

http://www.guidetopharmacology.org/GRAC/FamilyDisplayForward?familyld=778

Enzymes

SGPP1(sphingosine-1-phosphate phosphatase 1)

http://www.guidetopharmacology.org/GRAC/ObjectDisplayForward?objectld=2523

SGPP2(sphingosine-1-phosphate phosphatase 2)

http://www.guidetopharmacology.org/GRAC/ObjectDisplayForward?objectld=2524

Sphingosine 1-phosphate lyase

http://www.guidetopharmacology.org/GRAC/FamilyDisplayForward?familyld=777

Enzymes

sphingosine-1-phosphate lyase 1

http://www.guidetopharmacology.org/GRAC/ObjectDisplayForward?objectld=2522

\section{References}

1. Bagdanoff JT, Donoviel MS, Nouraldeen A, Carlsen M, Jessop TC, Tarver J, Aleem S, Dong L, Zhang H and Boteju $L$ et al.. (2010) Inhibition of sphingosine 1-phosphate lyase for the treatment of rheumatoid arthritis: discovery of (E)-1-(4-((1R,2S,3R)-1,2,3,4-tetrahydroxybutyl)-1H-imidazol-2-yl)ethanone oxime (LX2931) and (1R,2S,3R)-1-(2-(isoxazol-3-yl)-1H-imidazol-4-yl)butane-1,2,3,4-tetraol (LX2932). J. Med. Chem. 53: 8650-62 [PMID:21090716]

2. Billich $A$, Baumruker T, Beerli C, Bigaud M, Bruns C, Calzascia T, Isken A, Kinzel B, Loetscher E and Metzler B et al.. (2013) Partial deficiency of sphingosine-1-phosphate lyase confers protection in experimental autoimmune encephalomyelitis. PLOS ONE 8: e59630 [PMID:23544080]

3. Choi YJ and Saba JD. (2019) Sphingosine phosphate lyase insufficiency syndrome (SPLIS): A novel inborn error of sphingolipid metabolism. Adv Biol Regul 71: 128-140 [PMID:30274713]

4. Fleischmann R. (2012) Novel small-molecular therapeutics for rheumatoid arthritis. Curr Opin Rheumatol 24: 335-41 [PMID:22357358]

5. French KJ, Schrecengost RS, Lee BD, Zhuang Y, Smith SN, Eberly JL, Yun JK and Smith CD. (2003) Discovery and evaluation of inhibitors of human sphingosine kinase. Cancer Res. 63: 5962-9 [PMID:14522923]

6. French KJ, Zhuang Y, Maines LW, Gao P, Wang W, Beljanski V, Upson JJ, Green CL, Keller SN and Smith CD. (2010) Pharmacology and antitumor activity of ABC294640, a selective inhibitor of sphingosine kinase-2. J. Pharmacol. Exp. Ther. 333: 129-39 [PMID:20061445]

7. Lim KG, Sun C, Bittman R, Pyne NJ and Pyne S. (2011) (R)-FTY720 methyl ether is a specific sphingosine kinase 2 inhibitor: Effect on sphingosine kinase 2 expression in HEK 293 cells and actin rearrangement and survival of MCF-7 breast cancer cells. Cell. Signal. 23: 1590-5 [PMID:21620961]

8. Lépine S, Allegood JC, Edmonds Y, Milstien S and Spiegel S. (2011) Autophagy induced by deficiency of sphingosine-1-phosphate phosphohydrolase 1 is switched to apoptosis by calpain-mediated autophagyrelated gene 5 (Atg5) cleavage. J. Biol. Chem. 286: 44380-90 [PMID:22052905]

9. McNaughton M, Pitman M, Pitson SM, Pyne NJ and Pyne S. (2016) Proteasomal degradation of sphingosine kinase 1 and inhibition of dihydroceramide desaturase by the sphingosine kinase inhibitors, SKi or ABC294640, induces growth arrest in androgen-independent LNCaP-Al prostate cancer cells. Oncotarget 7: 16663-75 [PMID:26934645] 
10. Paugh SW, Paugh BS, Rahmani M, Kapitonov D, Almenara JA, Kordula T, Milstien S, Adams JK, Zipkin RE and Grant $S$ et al.. (2008) A selective sphingosine kinase 1 inhibitor integrates multiple molecular therapeutic targets in human leukemia. Blood 112: 1382-91 [PMID:18511810]

11. Schnute ME, McReynolds MD, Kasten T, Yates M, Jerome G, Rains JW, Hall T, Chrencik J, Kraus M and Cronin CN et al.. (2012) Modulation of cellular S1P levels with a novel, potent and specific inhibitor of sphingosine kinase-1. Biochem. J. 444: 79-88 [PMID:22397330]

12. Schwab SR, Pereira JP, Matloubian M, Xu Y, Huang Y and Cyster JG. (2005) Lymphocyte sequestration through S1P lyase inhibition and disruption of S1P gradients. Science 309: 1735-9 [PMID:16151014]

13. Venant H, Rahmaniyan M, Jones EE, Lu P, Lilly MB, Garrett-Mayer E, Drake RR, Kraveka JM, Smith CD and Voelkel-Johnson C. (2015) The Sphingosine Kinase 2 Inhibitor ABC294640 Reduces the Growth of Prostate Cancer Cells and Results in Accumulation of Dihydroceramides In Vitro and In Vivo. Mol. Cancer Ther. 14: 2744-52 [PMID:26494858]

14. Weiler S, Braendlin N, Beerli C, Bergsdorf C, Schubart A, Srinivas H, Oberhauser B and Billich A. (2014) Orally active 7-substituted (4-benzylphthalazin-1-yl)-2-methylpiperazin-1-yl]nicotinonitriles as active-site inhibitors of sphingosine 1-phosphate lyase for the treatment of multiple sclerosis. J. Med. Chem. 57: 5074-84 [PMID:24809814] 